\title{
UTILIZACIÓN POTENCIAL DE CÉLULAS MADRE EN ENFERMEDADES DEGENERATIVAS RETINIANAS
}

\section{STEM CELL POTENTIAL USES IN RETINAL DYSTROPHIES}

\author{
PINILLA I ${ }^{1}$, MARTÍN NIETO J ${ }^{2}$, CUENCA N ${ }^{2}$
}

\begin{abstract}
Desde hace unos 25 años se conoce el modo de obtener y mantener en cultivo las células madre de embriones de ratones (1). A finales del año 1998, y después de intensos trabajos de experimentación, un grupo de investigadores de la Universidad de Wisconsin (EEUU) consiguió el primer cultivo de células madre embrionarias humanas (2). A partir de ese momento, las células madre han sido presentadas como la gran esperanza terapéutica del nuevo siglo.

Las células madre embrionarias humanas son inmortales y tienen un potencial casi ilimitado de desarrollo. Tras mantenerse durante meses en cultivo, estas células mantienen la capacidad de diferenciarse en cualquier tipo celular. Esta capacidad proliferativa y de diferenciación promete la posibilidad de suministrar tipos celulares específicos para investigación básica o trasplante terapéutico, este último aplicado a diversos tipos de patologías como las enfermedades cardiacas, la leucemia, la diabetes, el Parkinson o las enfermedades degenerativas retinianas.
\end{abstract}

Las principales aplicaciones de la investigación de las células madre son: la identificación de los mecanismos de actuación de diferentes fármacos y evaluación de su potencial terapéutico; la comprensión, prevención y tratamiento de enfermedades congénitas; el estudio de la diferenciación celular a nivel de investigación básica y la obtención de tejidos y células para el trasplante. Una vez conseguida la diferenciación de las células madre en un tipo específico de célula precursora o madura, ésta podría ser empleada en la terapia de determinadas enfermedades humanas causadas por la muerte o disfunción de un tipo celular concreto (neuronas dopaminérgicas en el Parkinson, células productoras de insulina en la diabetes, fotorreceptores en la retinosis pigmentaria o células de epitelio pigmentario retiniano (EPR) en la DMAE.

Las líneas de células madre embrionarias humanas no son la única fuente posible de células con fines terapéuticos. Por ejemplo, a nivel de retina pueden obtenerse precursores neuronales a partir de ojos de fetos de embarazos no llegados a término, de células hematopoyéticas y del cordón umbilical. También se ha descrito la posibilidad de que existan células multipotenciales retinianas a nivel de la pars plana del cuerpo ciliar en humanos adultos (3), de modo similar a otros vertebrados como anfibios o peces.

La utilización de células embrionarias y fetales humanas en terapia celular ha suscitado repercusiones ético-sociales, además de las dificultades técnicas que supone conseguir su integración efectiva en el tejido receptor a nivel morfológico y funcional.

Existen todavía numerosas incógnitas por resolver sobre la diferenciación dirigida de las células madre hacia un tipo celular determinado. Se sabe que las células madre y progenitoras reciben instrucciones de determinados genes reguladores y también información de su entorno. El conjunto de estas señales es lo que dicta el destino de dichas células y determina qué tipo de tejido van a originar. Las células madre embrionarias pueden formar cuerpos embrioides en cultivo y pueden ser dirigidas a una diferenciación neural mediante la adición al medio de ácido retinoico o de FGF2 tras una fase de proliferación en presencia de distintos factores. La posterior diferenciación hacia neuronas retinianas puede conseguirse mediante el cocultivo con

\footnotetext{
1 Servicio de Oftalmología. Hospital Universitario Miguel Servet. Zaragoza. Instituto Aragonés de Ciencias de la Salud. E-mail: isabel.pinilla@telefonica.net

2 Departamento de Fisiología Genética y Microbiología. Facultad de Ciencias. Universidad de Alicante.
} 
células retinianas o la sobreexpresión de algún gen regulador (como $C r x$ ).

Las células madre en diferenciación hacia diversos tipos neuronales o células de EPR han sido utilizadas en terapias celulares en distintos modelos animales de retinosis pigmentaria, consiguiéndose en general una mejoría de la respuesta funcional y una conservación anatómica (4). Recientemente se ha observado el establecimiento de conexiones sinápticas correctas tras el trasplante de células postnatales precursoras de bastón en ratones ciegos (5).

Aunque existen aún numerosos problemas relativos a su utilización efectiva en pacientes, incluidas las barreras ético-legales, la terapia sustitutiva con células madre se presenta como un futuro prometedor en el tratamiento de un gran número de enfermedades neurodegenerativas de la retina.

\section{BIBLIOGRAFÍA}

1. Evans MJ, Kaufman MH. Establishment in culture of pluripotential cells from mouse embryos. Nature 1981; 292: 154-156.

2. Thomson JA, Itskovitz-Eldor J, Shapiro SS, Waknitz MA, Swiergiel JJ, Marshall VS, et al. Embryonic stem cell lines derived from human blastocysts. Science 1998; 282: 1145 1147.

3. Coles BL, Angenieux B, Inoue T, Del Rio-Tsonis K, Spence JR, McInnes RR, et al. Facile isolation and the characterization of human retinal stem cells. Proc Natl Acad Sci U S A 2004; 101: 15772-15777.

4. Lund RD, Wang S, Klimanskaya I, Holmes T, Ramos-Kelsey $R, L u B$, et al. Human embryonic stem cell-derived cells rescue visual function in dystrophic RCS rats. Cloning Stem Cells 2006; 8: 189-199.

5. MacLaren RE, Pearson RA, MacNeil A, Douglas RH, Salt TE, Akimoto $M$, et al. Retinal repair by transplantation of photoreceptor precursors. Nature 2006; 444: 203-207. 